\title{
AIR CONDITIONING AND SELECTED VEHICLE CHARACTERICTICS
}

UDC: 629.33

Original scientific paper

https://doi.org/10.18485/aeletters.2020.5.1.2

\author{
Tomáš Skrúcaný ${ }^{1}$, František Synák ${ }^{1 *}$, Martin Kendra², Saša Milojević ${ }^{3}$ \\ ${ }^{1}$ University of Žilina, Faculty of operation and economics of transport and communications, Department of \\ road and urban transport, Slovakia \\ ${ }^{2}$ University of Žilina, Faculty of operation and economics of transport and communications, Department of \\ railway transport, Slovakia \\ ${ }^{3}$ University of Kragujevac, Faculty of Engineering, Department for Motor Vehicles and IC Engines, Serbia
}

\begin{abstract}
:
The main purpose of the paper is to determine the change in vehicle energy efficiency due to using the air conditioning system. There is a connection between the changes in vehicle energy efficiency and fuel consumption together with time needed for vehicle acceleration. The paper comprises the measurement results performed at stabilized speeds as well as during vehicle acceleration. The final part of the paper outlines the result of calculation of change in vehicle energy efficiency resulting from air conditioning unit used during New European Driving Cycle.
\end{abstract}

\section{ARTICLE HISTORY}

Received: 20.02.2020.

Accepted: 06.03.2020.

Available: 31.03.2020.

\section{KEYWORDS}

Acceleration, air condition, energy intensity, engine power, fuel consumption

\section{INTRODUCTION}

The high temperature in a vehicle interior affects drivers as well as driving safety negatively $[1,2]$. Reaching up the temperature about $30^{\circ} \mathrm{C}$ that is common in an overheated vehicle; the driver's response time extends for $65 \%$ after ninety minutes. It is a condition comparable with an effect caused by $0.5 \%$ blood alcohol level $[3$, 4]. To reduce the interior temperature in a vehicle must also be the role of air conditioning system that contributes to convenience of drivers and other passengers, and thus to increasing road safety $[5,6]$. Besides the summer period during which the air-conditioning is used for cooling the vehicle interior, it is also used in the winter period for air drying in order to prevent the windows from being fogged up [7].

A driving generator of air conditioning system is a compressor which is driven by a vehicle engine. Concerning manual air conditioner, the compressor works at full power under any conditions. There is only one condition for compressor's operation, and thus to be started up. The resulting temperature is regulated by stirring the warm air [8].

Concerning automatic air conditioner, the compressor does not work at full power at any time. Unless there is no need to cool the vehicle interior down significantly, the air conditioning system disconnects the compressor; the power of air conditioner is being reduced and so the consumption of the engine power [9].

The first aspect explored is the impact of using the air-conditioning system while driving at constant speed. The second one is the impact of using the air conditioning system on the vehicle's ability to accelerate both on ground and gradient level. The impact of using the vehicle air conditioning on its energy efficiency has been also studied during New European Driving Cycle (NEDC). It is also referred to as MVEG cycle (Motor Vehicle Emissions Group).

The results point out that there is an appreciable impact of using the vehicle airconditioning within the framework of all the three scopes explored. 


\section{EXPERIMENTAL SETUP}

The measurements of change in the engine energy efficiency as a result of using the airconditioning unit have been conducted at the vehicle dynamometer MAHA MSR 1050 with its measurement deviation of $2 \%$ given by the manufacturer $[10,14]$. The vehicle dynamometer enables to simulate driving of particular vehicle on both ground and gradient level. Such simulation is done by dynamometer cylinder's acceleration or deceleration [11].

The measurements have been performed with passenger vehicle (Maker: KIA; type: Ceed 1.6 (VVT).

Technical data of vehicle and engine used during measurements are shown in the Table 1.

Table 1. Technical parameters of vehicle used during experiments [12]

\begin{tabular}{|c|c|}
\hline Description & Specification \\
\hline Vehicle & KIA Ceed 1.6 CVVT \\
\hline $\begin{array}{c}\text { Mass in running order } \\
\text { Gross vehicle weight }\end{array}$ & $1163 \mathrm{~kg}$ \\
\hline Vehicle acceleration & $0-100 \mathrm{~km} / \mathrm{hg}(10.8 \mathrm{~s})$ \\
\hline & $\begin{array}{c}1.6 \mathrm{CVVT}(\mathrm{Hyundai}) \\
\text { Gasoline, } 4-\mathrm{L}, \\
\text { Engine specification } \\
90 \mathrm{~kW} \text { at } 6200(1 / \mathrm{min}) \\
154 \mathrm{Nm} \text { at } 5200(1 / \mathrm{min})\end{array}$ \\
\hline Fuel injection system & $\begin{array}{c}\text { Multi point injection }(\mathrm{MPI}) \\
\text { Spark ignition }\end{array}$ \\
\hline Gearbox & Automatic with $5 \mathrm{speed}$ \\
\hline Fuel consumption & $\begin{array}{c}\text { Urban }-8.0(\mathrm{l} / 100 \mathrm{~km}) \\
\text { Extra-urban }-5.4(\mathrm{l} / 100 \mathrm{~km}) \\
\text { Combined }-6.4(\mathrm{l} / 100 \mathrm{~km})\end{array}$ \\
\hline $\mathrm{CO}_{2}$ emissions & $152(\mathrm{~g} / \mathrm{km})$ \\
\hline Air conditioning & Automatic, 1 zone \\
\hline system $(\mathrm{A} / \mathrm{C})$ & \\
\hline
\end{tabular}

The vehicle is equipped with an automatic $(\mathrm{A} / \mathrm{C})$ system. The measurements were always taken when the compressor was operating and air conditioner was cooling the vehicle interior from $21^{\circ} \mathrm{C}$ down to $17^{\circ} \mathrm{C}$.

Fuel consumption measurement was performed via fuel flow meter AIC 1203 with its measurement accuracy of $1 \%[10,13]$. The scheme of connection during measurement is shown in the Fig.1.

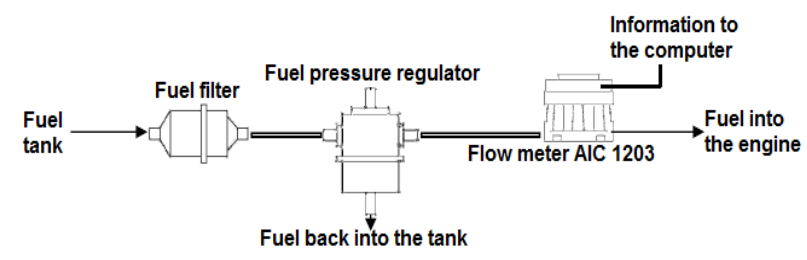

Fig. 1. Scheme of flow meter AIC 1203 connection
Before measuring, it is necessary to insert the vehicle parameters into the dynamometer computer. These include a power needed for overcoming the air and rolling resistances at the driving speed of $90 \mathrm{~km} / \mathrm{h}$ as well as mass of the vehicle in running order [14].

The power needed for overcoming the air resistance was calculated according to relation (1) $[15,16]$ :

$$
P_{a}=\frac{1}{2} \cdot \rho \cdot c_{x} \cdot S \cdot v^{3}
$$

Where is:

- $P_{a}$ - engine power for air resistances, $W$;

- $\rho$ - air density, $\mathrm{kg} / \mathrm{m}^{3}$;

- $c_{x}$ - air resistance coefficient, -

- $S$ - vehicle front area, $m^{2}$; and

- $v$ - vehicle speed, $\mathrm{m} / \mathrm{s}$.

The power needed for overcoming the rolling resistance would have been calculated according to relation (2) [17]:

$$
P_{r}=m \cdot g \cdot f \cdot v
$$

Where is:

- $P_{r}$ - engine power for rolling resistances, $W$;

- $m$ - instantaneous vehicle mass, $k g$;

- $g$ - gravitational acceleration, $\mathrm{m} / \mathrm{s}^{2}$;

- $f$ - tyre resistance coefficient, - ; and

- $v$ - vehicle speed, $\mathrm{m} / \mathrm{s}$.

The measurements of the impact of $(A / C)$ unit while driving at constant speed have been divided into three most common running orders of driving. These are specifically areas of speed of $50 \mathrm{~km} / \mathrm{h}$ which is the maximum permissible driving speed in most towns and villages within the European Union; speed of $90 \mathrm{~km} / \mathrm{h}$ which is the maximum permissible driving speed outside towns and villages, and speed of $130 \mathrm{~km} / \mathrm{h}$ which is the maximum permissible driving speed in highways.

Each measurement has involved the calculation of the engine energy given in the form of work as well as its energy got from fuel. The engine energy can by calculated according to formula (3) [18]:

$$
W=P_{e} \cdot t
$$

Where is:

- $W$ - energy given by engine, $J$, 
- $P_{e}$ - engine power, $W$; and

$-t$ - time of measuring, $s$.

The engine power has been calculated as follows; equation (4) [19]:

$$
P_{e}=P_{w} \cdot \eta_{m}
$$

Where is:

- $P_{w}$ - power on wheels, and

- $\eta_{m}$ - mechanical efficiency of drive line and wheel rolling.

The common value of mechanical efficiency for driveline (in vehicles driven by front axles) is at the level of $7 \%$ [20].

The energy delivered in the form of chemical energy in fuel can be calculated as follows, according to equation (5) [21]:

$$
E=m_{f} \cdot H_{d}
$$

Where is:

- $E$ - energy delivered into engine in the form of fuel, $J$;

- $m_{f}$ - consumed fuel mass, $\mathrm{kg}$; and

- $H_{d}$ - low heating value of fuel, $\mathrm{J} / \mathrm{kg}$.

The low heating value of fuel used for this calculation has been considered as $\boldsymbol{H}_{\boldsymbol{d}}=$ $43929 \mathrm{~kJ} / \boldsymbol{k g}$ [22].

The total level of energy efficiency of the proces (vehicle drive) $\left(\boldsymbol{\eta}_{\boldsymbol{f}}\right)$ can be further calculated as ratio of energy gained to energy spent; equation (6) [23]:

$$
\eta_{f}=\frac{E}{W}
$$

The goal of the second part of measurements was to determine the impact of using the $(A / C)$ system on vehicle acceleration.

The measurements have been performed with having the acceleration pedal fully applied. The vehicle has accelerated from the speed of $50 \mathrm{~km} / \mathrm{h}$ to speed of $80 \mathrm{~km} / \mathrm{h}$ with the third transmission gear used, and also from the speed of $80 \mathrm{~km} / \mathrm{h}$ to speed of $120 \mathrm{~km} / \mathrm{h}$ with the fourth transmission gear used. Such accelerations were measured gradually at $0 \%, 2 \%$ and $4 \%$ gradient.

The third part includes the calculation of engine energy efficiency needed for driving NEDC cycle with and without having the air conditioner applied.
3. RESULTS

\subsection{Impact of air conditioner applied on fuel consumption at constant speed of $50 \mathrm{~km} / \mathrm{h}$}

The first measurement was done with the constant speed of $50 \mathrm{~km} / \mathrm{h}$, firstly without having the air conditioner applied and then with it. The results are given in the Table 2.

Table 2. Impact of air conditioner applied on fuel consumption at constant speed of $50 \mathrm{~km} / \boldsymbol{h}$

\begin{tabular}{|c|c|c|}
\hline \multirow{2}{*}{ Parameters } & \multicolumn{2}{|c|}{ Air conditioner applied } \\
\cline { 2 - 3 } & No & Yes \\
\hline $\begin{array}{c}\text { Fuel consumption } \\
(l / 100 \mathrm{~km})\end{array}$ & 4.612 & 5.745 \\
\hline $\begin{array}{c}\text { Energy spent } \\
(\mathrm{kWh})\end{array}$ & 0.110 & 0.146 \\
\hline $\begin{array}{c}\text { Energy delivered in } \\
\text { the fuel, }(\mathrm{kWh})\end{array}$ & 0.839 & 1.182 \\
\hline $\begin{array}{c}\text { Efficiency } \\
(\%)\end{array}$ & 13.09 & 12.36 \\
\hline
\end{tabular}

As seen from the Table 2, having the air conditioner applied while driving at constant speed of $50 \mathrm{~km} / \mathrm{h}$ has increased the fuel consumption by $24 \%$.

\subsection{Impact of air conditioner applied on fuel consumption at constant speed of $90 \mathrm{~km} / \mathrm{h}$}

The first measurement was done with the constant speed of $90 \mathrm{~km} / \mathrm{h}$, firstly without having the air conditioner applied and then with it. The results are given in the Table 3.

Table 3. Impact of air conditioner applied on fuel consumption at constant speed of $90 \mathrm{~km} / \boldsymbol{h}$

\begin{tabular}{|c|c|c|}
\hline \multirow{2}{*}{ Parameters } & \multicolumn{2}{|c|}{ Air conditioner applied } \\
\cline { 2 - 3 } & No & Yes \\
\hline $\begin{array}{c}\text { Fuel consumption } \\
(l / 100 \mathrm{~km})\end{array}$ & 5.206 & 5.701 \\
\hline $\begin{array}{c}\text { Energy spent } \\
(k W h)\end{array}$ & 0.224 & 0.224 \\
\hline $\begin{array}{c}\text { Energy delivered in } \\
\text { the fuel, }(k W h)\end{array}$ & 1.045 & 1.139 \\
\hline $\begin{array}{c}\text { Efficiency } \\
(\%)\end{array}$ & 21.44 & 19.68 \\
\hline
\end{tabular}

While driving at the speed of $90 \mathrm{~km} / \mathrm{h}$, lower increase in fuel consumption than in the previous case. The increase was $9.5 \%$. 


\subsection{Impact of air conditioner applied on fuel consumption at constant speed of $130 \mathrm{~km} / \mathrm{h}$}

The values measured while driving at the speed of $130 \mathrm{~km} / \mathrm{h}$, are given in the Table 4 .

Table 4. Impact of air conditioner applied on fuel consumption at constant speed of $130 \mathrm{~km} / \mathrm{h}$

\begin{tabular}{|c|c|c|}
\hline \multirow{2}{*}{ Parameters } & \multicolumn{2}{|c|}{ Air conditioner applied } \\
\cline { 2 - 3 } & No & Yes \\
\hline $\begin{array}{c}\text { Fuel consumption } \\
(l / 100 \mathrm{~km})\end{array}$ & 7.633 & 7.831 \\
\hline $\begin{array}{c}\text { Energy spent } \\
(\mathrm{kWh})\end{array}$ & 0.403 & 0.393 \\
\hline $\begin{array}{c}\text { Energy delivered in } \\
\text { the fuel, }(\mathrm{kWh})\end{array}$ & 1.515 & 1.548 \\
\hline $\begin{array}{c}\text { Efficiency } \\
(\%)\end{array}$ & 26.59 & 25.37 \\
\hline
\end{tabular}

While driving at the speed of $130 \mathrm{~km} / \mathrm{h}$, the difference measured due to air conditioning unit used was only $0.198 \mathrm{l} / 100 \mathrm{~km}$, that means $2.6 \%$ increase in fuel consumption.

For better transparency, the measurement results are also given in the graph in the Fig. 2 .

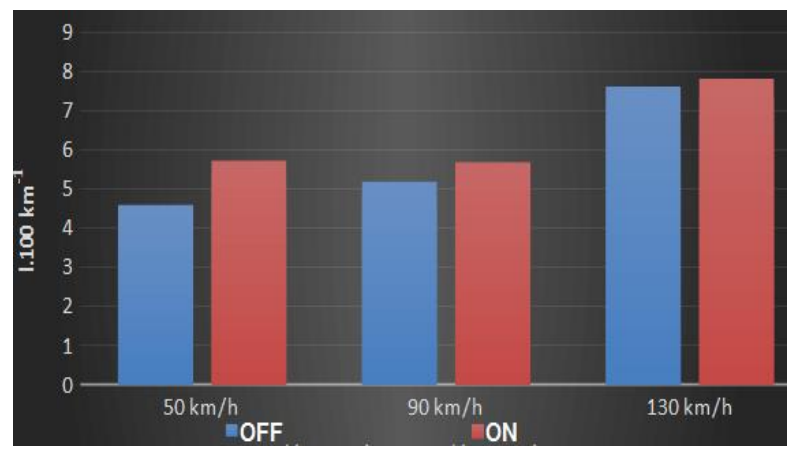

Fig. 2. Impact of air conditioner on fuel consumption while driving at constant speed on level ground

Concerning the air conditioner used, the lowest impact on fuel consumption has been seen at the speed of $130 \mathrm{~km} / \mathrm{h}$, at which the fuel consumption increase represents only $2.5 \%$. The reason lies in that the power needed for overcoming driving resistances had the highest value of $23.7 \mathrm{~kW}$ alongside of which the value of power needed for the air conditioner's compressor operation represented only a small part. It can also be assumed that there is a reduction of brake specific fuel consumption (BSFC) by higher engine load [24]. On the other hand, while driving at constant speed of $50 \mathrm{~km} / \mathrm{h}$, the power needed for overcoming driving resistances had the lowest value of $2.62 \mathrm{~kW}$, and thus, the increase in fuel consumption resulting from the $(\mathrm{A} / \mathrm{C})$ system used was the highest.

\subsection{Impact of air conditioner applied on vehicle acceleration}

The goal of the second part of measurements was to determine the impact of using the $(A / C)$ system on vehicle acceleration. The measurement results during acceleration from 50 to $80 \mathrm{~km} / \mathrm{h}$ are given in the Table 5 .

Table 5. Impact of air conditioner applied on vehicle acceleration from 50 to $80 \mathrm{~km} / \mathrm{h}$

\begin{tabular}{|c|c|c|c|c|}
\hline \multirow{2}{*}{$\begin{array}{c}\text { Gradient } \\
\text { (\%) }\end{array}$} & \multirow{2}{*}{$\begin{array}{c}\mathrm{A} / \mathrm{C} \\
\text { system }\end{array}$} & \multicolumn{3}{|c|}{$\begin{array}{c}\text { Acceleration } \\
50-80 \mathrm{~km} / \mathrm{h}\end{array}$} \\
\hline & & $\begin{array}{l}\text { Time } \\
(s)\end{array}$ & $\begin{array}{l}\text { Value } \\
\left(\mathrm{m} / \mathrm{s}^{2}\right)\end{array}$ & $\begin{array}{c}\text { Difference } \\
(\%)\end{array}$ \\
\hline 0 & Off & 5.559 & 1.488 & \multirow{2}{*}{-6.923} \\
\hline 0 & On & 6.017 & 1.385 & \\
\hline 2 & Off & 6.538 & 1.275 & \multirow{2}{*}{-9.490} \\
\hline 2 & On & 7.222 & 1.154 & \\
\hline 4 & Off & 8.314 & 1.002 & \multirow{2}{*}{-11.477} \\
\hline 4 & On & 9.394 & 0.887 & \\
\hline
\end{tabular}

As seen from the Table 5, using of the air conditioner during acceleration leads to reduction of acceleration value, i.e. to increase of time needed for reaching a certain speed. The highest decrease in acceleration $(11.477 \%)$ has been seen while overcoming the highest gradient of $4 \%$ with the increase of time by $1.08 \mathrm{~s}$.

The graph in the Fig. 3 shows the impact of switching on the air conditioner on time needed for acceleration from $50 \mathrm{~km} / \mathrm{h}$ to the speed of $80 \mathrm{~km} / \mathrm{h}$.

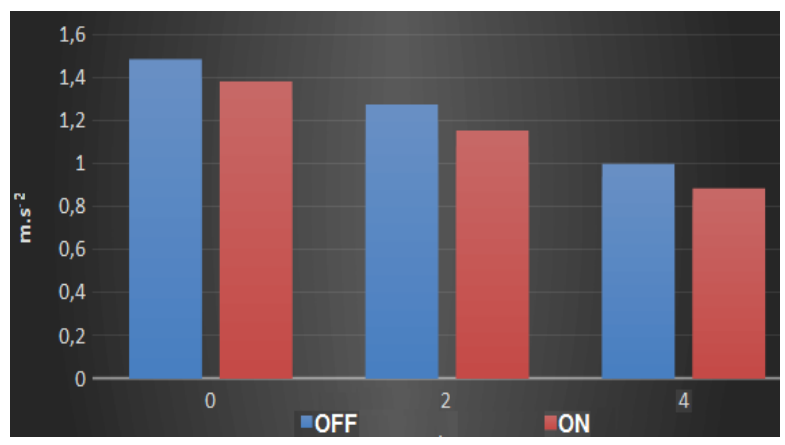

Fig. 3. Impact of $(A / C)$ system on vehicle acceleration

Increasing road gradient leads to decrease in vehicle ability to accelerate as seen in the Fig.4, too. The reason is that together with increasing road gradient there is an increase in the engine power needed for overcoming such gradient. Therefore, there is little engine power left for vehicle acceleration. And, using the $(\mathrm{A} / \mathrm{C})$ system 
limits the vehicle ability to accelerate even more during increasing gradient [25].

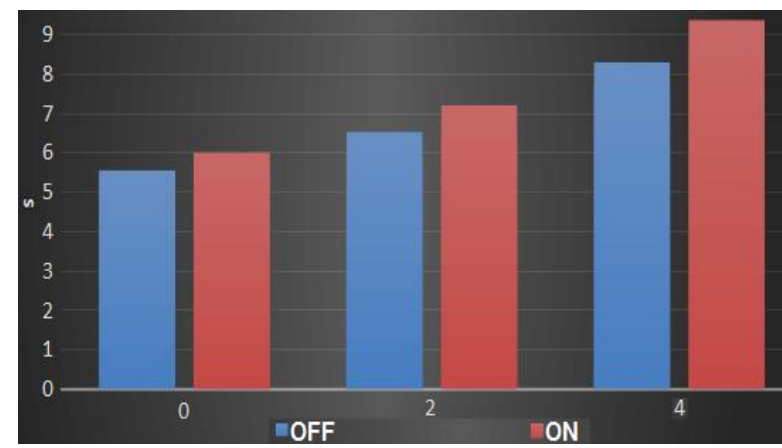

Fig. 4. Impact of (A/C) system on time needed for reaching a certain vehicle speed

The results of impact of air conditioning used during acceleration from 80 to $120 \mathrm{~km} / \mathrm{h}$ are given in the Table 6 .

Table 6. Impact of air conditioner applied on vehicle acceleration from 80 to $120 \mathrm{~km} / \mathrm{h}$

\begin{tabular}{|c|c|c|c|c|}
\hline \multirow{2}{*}{$\begin{array}{c}\text { Gradient } \\
(\%)\end{array}$} & \multirow{2}{*}{$\begin{array}{c}\text { A/C } \\
\text { system }\end{array}$} & \multicolumn{3}{|c|}{$\begin{array}{c}\text { Acceleration } \\
80-120 \mathrm{~km} / \mathrm{h}\end{array}$} \\
\cline { 3 - 4 } & & $\begin{array}{c}\text { Time } \\
(\mathrm{s})\end{array}$ & $\begin{array}{c}\text { Value } \\
\left(\mathrm{m} / \mathrm{s}^{2}\right)\end{array}$ & $\begin{array}{c}\text { Difference } \\
(\%)\end{array}$ \\
\hline 0 & Off & 11.913 & 0.933 & \multirow{2}{*}{-14.041} \\
\hline 0 & On & 13.855 & 0.802 & \\
\hline 2 & Off & 15.614 & 0.712 & \multirow{2}{*}{-24.719} \\
\hline 2 & On & 20.738 & 0.536 & \\
\hline 4 & Off & 23.153 & 0.480 & \multirow{2}{*}{-18.125} \\
\hline 4 & On & 28.294 & 0.393 & \\
\hline
\end{tabular}

For better transparency, the results are also given in the form of graphs in the Fig. 5 and 6.

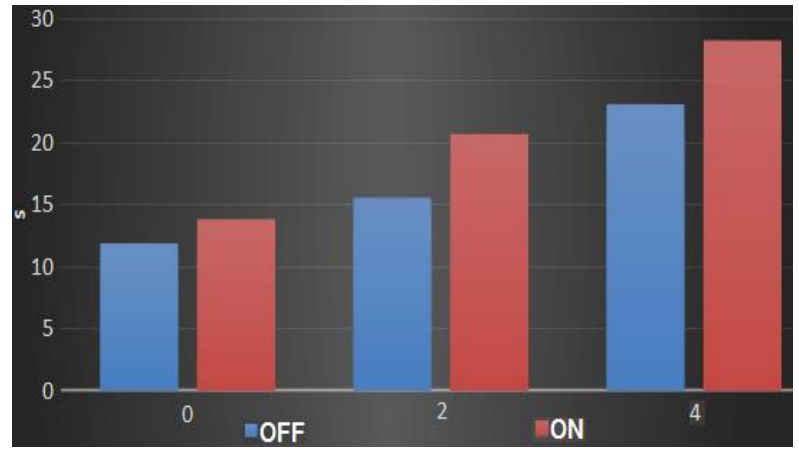

Fig. 5. Impact of (A/C) system on time needed for vehicle acceleration

By comparing the above results from the Fig. 5 and 6 , it implies that during acceleration from 80 to $120 \mathrm{~km} / \mathrm{h}$, the air conditioner has bigger impact than during acceleration from 50 to $80 \mathrm{~km} / \mathrm{h}$.

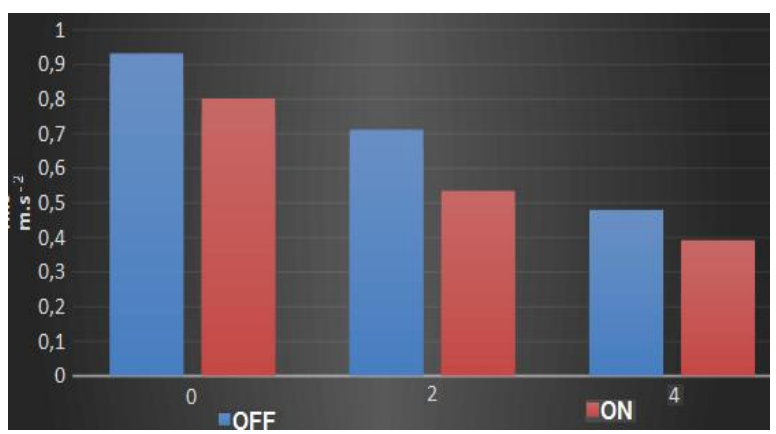

Fig. 6. Impact of (A/C) system on vehicle acceleration

\subsection{Impact of air conditioner applied on vehicle acceleration}

NEDC represents a driving cycle composed of four driving urban cycles and one extra-urban, Fig.7 [26].

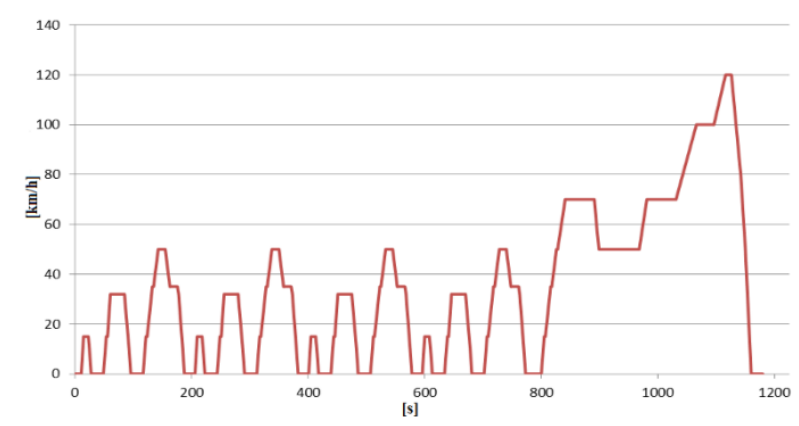

Fig. 7. NEDC driving cycle

The rules of this test provide that there must be used only appliances necessary for the engine and vehicle running. It means that, according to these rules, it is not possible to assess the impact of air-conditioning system on power, fuel consumption and the engine energy efficiency.

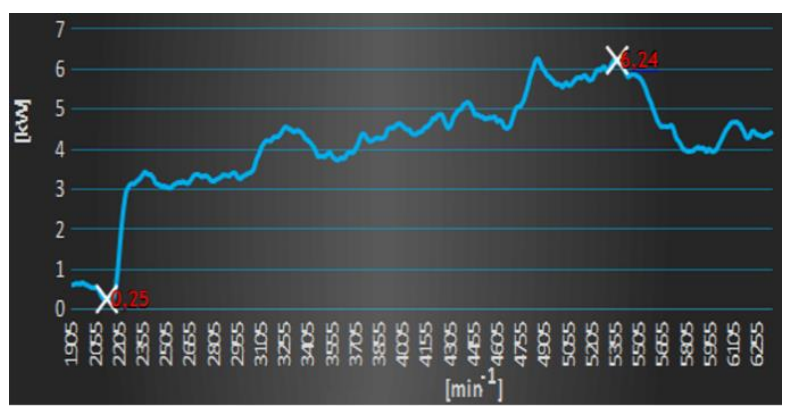

Fig. 8. Engine power needed for the $(A / C)$ compressor to be driven depending on the engine speed

However, the results from the previous measurements can be applied to this test in order to have the courses of powers needed for overcoming NEDC cycle with or without having the $(A / C)$ system used while driving [25]. The power that is necessary for the $(A / C)$ compressor 
to be driven depending on the engine speed is displayed in the Fig.8.

When having the air conditioner switched off, the engine power can be increased by a power needed for compressor to be driven, and thus it can be calculate the course of power which is necessary to overcome NEDC cycle with or without having the air conditioner used, Fig.9.

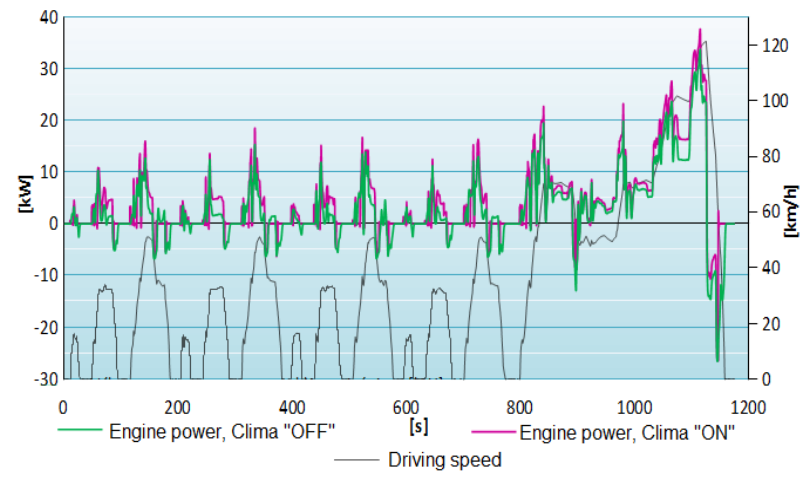

Fig. 9. Engine power needed while driving according to NEDC with or without the air conditioner used

It can be seen in the Fig.9 what is the power needed during NEDC cycle with having the air conditioner switched off and on. When having the air conditioner applied, there must always be a higher power produced. Such increase in the power produced is caused by the compressor which takes its power from the engine.

The energy needed for driving this cycle has the value of $1.209 \mathrm{kWh}$ without $(\mathrm{A} / \mathrm{C})$ system used and value of $1.443 \mathrm{kWh}$ with the air conditioner applied. It means that the airconditioning system would consume $0.234 \mathrm{kWh}$ of energy delivered during the cycle. The overall energy consumed has been calculated as an accumulative sum of energies at particular engine speeds. The powers with negative values during vehicle decelerations have not been taken into consideration in this case since there is not any energy recuperation in the spark ignition engine.

\section{CONCLUSIONS}

The purpose of the measurements was to assess the impact of using the $(A / C)$ system on selected aspects.

The first part of the measurements payed attention to the impact of air conditioning unit used while driving at constant speed of $50 \mathrm{~km} / \mathrm{h}, 90 \mathrm{~km} / \mathrm{h}$ and $130 \mathrm{~km} / \mathrm{h}$ on ground level. The highest increase, by $1.133 \mathrm{l} / 100 \mathrm{~km}$, in fuel consumption has been caused by using the air conditioner while driving at the speed of $50 \mathrm{~km} / \mathrm{h}$ i.e. from $4.6 \mathrm{l} / 100 \mathrm{~km}$ to $5.7 \mathrm{l} / 100 \mathrm{~km}$. Such increase in fuel consumption represents a significant change in vehicle energy efficiency. It is necessary to bear in mind that every litre of petrol leads to production of $2.5 \mathrm{~kg}$ of $\mathrm{CO}_{2}$ as well as to consumption of about $15 \mathrm{~m}^{3}$ of air $[27,28]$. Thus, increasing the fuel consumption by 1.133 $l / 100 \mathrm{~km}$ causes an increase in carbon dioxide production by $2.83 \mathrm{~kg} \mathrm{CO} / 100 \mathrm{~km}$ as well as consumption of $17 \mathrm{~m}^{3}$ of air additionally per every $100 \mathrm{~km}$ driven resulting from the air conditioner used. Together with increasing driving speed, there has been also measured a lower impact of $(A / C)$ system on change of vehicle energy efficiency.

The purpose of the second part of measurements was to determine the impact of $(\mathrm{A} / \mathrm{C})$ system used on vehicle energy efficiency and its ability to accelerate. Vehicle ability to accelerate as far as possible in a short time affects the level of vehicle active safety. As seen from the results measured in the article, using the air-conditioner decreases vehicle ability to accelerate. According to these results, having the air conditioner applied while driving with gradient of $2 \%$ can increase time to accelerate from 50 to $80 \mathrm{~km} / \mathrm{h}$ by $0.68 \mathrm{~s}$. Drivers are not often aware of the $(\mathrm{A} / \mathrm{C})$ compressor active operation, and what is more, $2 \%$ gradient cannot be many a time noticed. During the previous manoeuvre may be the period of $0.68 s$ a time which can absent when finishing it safely.

Using the $A / C$ has different impact on the fuel consumption which depends on the actual operation conditions like actual ambient temperature, engine volume, $\mathrm{A} / \mathrm{C}$ compressor type, vehicle, speed, engine speed and others [29].

The impact of having the air conditioner used on change in the vehicle energy efficiency has also been proven definitely in the third part of this article. According to the calculations, having the air conditioner switched on would have caused a significant increase in vehicle energy efficiency even during the NEDC test.

\section{ACKNOWLEDGMENT}

Contribution has been prepared on the basis of the grant: 
VEGA no. 1/0436/18 - Externalities in road transport, an origin, causes and economic impacts of transport measures.

This manuscript was supported within solving the research project TR35041 financed by the Ministry of Science and Techno-logical development of the Republic of Serbia.

\section{REFERENCES}

[1] X.J. Zhou, D.Y. Lai, Q.Y. Chen, Experimental investigation of thermal comfort in a passenger car under driving conditions. Building and Envioment, 149, 2019: 109-119.

https://doi.org/10.1016/j.buildenv.2018.12.022

[2] A. Kalasova, L. Cernicky, M. Hamar, A New Approach to Road Safety in Slovakia. Telematics in the Transport Environment, 329, 2012: 388-395.

https://doi.org/10.1007/978-3-642-34050-5 44

[3] A.K. Yadav, N.R. Velaga, Modelling the relationship between different Blood Alcohol Concentrations and reaction time of young and mature drivers. Transportation Research Part F: Traffic Psychology and Behaviour, 64, 2019: 227-245.

https://doi.org/10.1016/j.trf.2019.05.011

[4] D. Topolsek, A. Mocic, K. Knez, M. Sternard, Young drivers under the influence of alcohol and their impact on the road traffic safety. Scientific journal of Silesian University series transport, 89, 2015: 85-98.

[5] J. Kapusta, and A. Kalasova, Motor Vehicle Safety Technologies in Relation to the Accident Rates. In: Mikulski J. (eds) Tools of Transport Telematics, TST 2015. Communications in Computer and Information Science, Vol.531. Springer, Cham, Berlin, 2015.

https://doi.org/10.1007/978-3-319-24577-5 17

[6] L. Moravcik, M. Jaskiewicz, Boosting car safety in the EU, $11^{\text {th }}$ International Scientific and Technical Conference on Automotive Safety, 2018.

[7] M. Fabrizio, C. Giulio, D.A. Alessandra, CFD methodology to predict demisting phenomena on the car windows, Proceedings of the $8^{\text {th }}$ Biennial Conference on Engineering Systems Design and Analysis, Vol.4, 2006: pp.281-287.
https://doi.org/10.1115/ESDA2006-95398

[8] J.D.A.P. Abraham, M. Mohanraj, Thermodynamic performance of automobile air conditioners working with R430A as a drop-in substitute to R134a. J Therm Anal Calori, 136, 2019: 2071-2086.

https://doi.org/10.1007/s10973-018-7843-1

[9] C.L. Weng, LJ. Kau, Design and Implementation of a Low-EnergyConsumption Air-Conditioning Control System for Smart Vehicle. Journal of Healthcare Engineering, 2019, Article ID 3858560, 2019: 1-14.

https://doi.org/10.1155/2019/3858560

[10] B. Šarkan, Š. Semanová, V. Harantová, O. Stopka, M. Chovancová, M. Szala, Vehicle fuel consumption prediction based on the data record obtained from an engine control unit, 3rd International Conference of Computational Methods in Engineering Science (CMES), Vol.252, Article number 06002, 2019.

https://doi.org/10.1051/matecconf/2019252060 $\underline{09}$

[11] B. Šarkan, O. Stopka, Quantification of road vehicle performance parameters under laboratory conditions. Adv. Sci. Technol. Res. J., 12(3), 2018: 16-23.

https://doi.org/10.12913/22998624/92107

[12] Kia Ceed 1.6 CVVT X-tra specs. https://www.cars-data.com/en/kia-ceed1.6-cvvt-x-tra-specs/18900 (Accessed 16.11.2019).

[13] Fuel Flow Meter AIC 1200 series, Technical information.http://reicon.us/TIcurrent/1200 LTI\%201000 e 07.08.pdf

[14] MAHA MSR 1050, Technical information. https://www.maha.de/single-rollerdynamometer-msr-1050.htm

[15] I. Janoško, T. Polonec, R. Simor, Electronic encyklopedia of construction engines and vehicles, 41st International Scientific Conference of Czech and Slovak University Departments and Institutions Dealing with the Research of Internal Combustion Engines, 2010, pp.232-238,

[16] T. Skrúcaný, Š. Semanová, S. Milojević, A. Ašonja, New technologies iproving aerodynamic properties of freight vehicles. 
Applied Engineering Letters, 4(2), 2019: 4854.

https://doi.org/10.18485/aeletters.2019.4.2.2

[17] J. Radosavljevic, A. Djordjevic, B. Zlatkovic, B. Samardzic, Compensation of Influence of Protector Compression Coefficients in Tyre Industry. Applied Engineering Letters, 4(1), 2019: 33-39.

https://doi.org/10.18485/aeletters.2019.4.1.5

[18] R. Pesic, S. Milojevic, Efficiency and ecological characteristics of a VCR diesel engine. Int.J Automot. Technol. 14, 2013: 675-681.

https://doi.org/10.1007/s12239-013-0073-4

[19] A. Skulic, B. Stojanovic, S. Radosavljevic, S. Velikovič, Experimental determination of worm gearing efficiency. Applied engineering letters, 4(4), 2019: 115-119.

https://doi.org/10.18485/aeletters.2019.4.4.2

[20] J. Jablonicky, J. Hujo, Z. Tkac, J. Kosiba, A. Zikla, Comparison of two designs of differential planetary gear with differential in output. Materials, technologies and quality assurance, 801, 2013: 13-18.

https://doi.org/10.4028/www.scientific.net/amr. $\underline{801.13}$

[21] T. Skrucany, S. Milojevic, S. Semanova, T. Cechovic, The energy efficiency of eletric energy as a traction used in transport. Transport technic and technology, 14(2), 2018: 9-14.

https://doi.org/10.2478/ttt-2018-0005

[22] A. Garcia, J. Monsalve Serarno, D. Villalta, R. Sari, Octane number influence on combustion and performance parameters in a Dual-Mode Dual-Fuel engine. Fuel, 258, 2019: Article 116140.

https://doi.org/10.1016/i.fuel.2019.116140

[23] T. Skrúcaný, M. Kendra, O. Stopka, S. Milojević, T. Figlus, C. Csiszár, Impact of the Electric Mobility Implementation on the Greenhouse Gases Production in Central
European Countries. Sustainability, 11(18), 2019: 1-15.

https://doi.org/10.3390/su11184948

[24] Z. Tian, X. Zhen, Y. Wang, D. Liu, X. Li, Comparative study on combustion and emission characteristics of methanol, ethanol and butanol fuel in TISI engine, Fuel, 259, 2020: Article 116241

https://doi.org/10.1016/j.fuel.2019.116199

[25] COMMISSION IMPLEMENTING REGULATION (EU) of 16.7.2018 amending Implementing Regulation (EU) 2017/1153 to clarify and simplify the correlation procedure and to adapt it to changes to Regulation (EU) 2017/1151.

[26] J. Pavlovic, B. Giuffo, G. Fontaras, V. Valverede, A. Marotta, How much difference in type-approval $\mathrm{CO}_{2}$ emissions from passenger cars in Europe can be expected from changing to the new test procedure (NEDC vs. WLTP)? Transportation Research Part A: Policy and Practice, 111, 2018: 136147.

https://doi.org/10.1016/j.tra.2018.02.002

[27] S. Narayn, S. Milojevic, V. Gupta, Combustion monitoring in engines using accelerometer signals. Journal of Vibroengineering, 21(6), 2019: 1552-1563.

https://doi.org/10.21595/ive.2019.20516

[28] L.N. Bortnikov, Combustion of a gasolinehydrogen-air mixture in a reciprocating internal combustion engine cylinder and determining the optimum gasolinehydrogen ratio. Combust Explos Shock Waves, 43, 2007: 378-383.

https://doi.org/10.1007/s10573-007-0052-z

[29] Stojanović B, Milojević S. Characterization, manufacturing and application of metal matrix composites. Advances in materials science research, $30^{\text {th }}$ edn. Nova Science Publishers, New York. 2017: 83-133. 